Vol. 6, No. 1, April 2018, pp. 1 4

\title{
Representasi Budaya Suku Tidore dalam Trailer Suanggi
}

Yul Isti Masri ${ }^{1}$

${ }^{1}$ Side Chanel Ahmad Dahlan, Universitas Ahmad Dahlan, Indonesia

\begin{tabular}{l}
\hline \hline Article Info \\
\hline Article history: \\
Received February 5, 2018 \\
Accepted March 25, 2018 \\
\end{tabular}

\section{Keywords:}

Representasi

Budaya Suku Tidore

Trailer

Suanggi

\begin{abstract}
Penelitian ini bertujuan untuk mengetahui budaya suku Tidore melalui trailer Suanggi, dan objek dari penelitian ini adalah trailer Suanggi. Trailer Suanggi mempunyai maksud serta pesan tentang kebudayaan, adanya nilai adat istiadat serta kepercayaan maupun keyakinan yang sudah dikemas sedemikian rupa dalam trailer tersebut. Kebudayaan sendiri hingga saat ini sudah melekat pada masyarakat Indonesia terlebih lagi pada masyarakat Tidore sendiri dengan kebudayaan yang ada. Trailer dari film Suanggi merupakan sebuah cerita yang berasal dari Tidore. Metode yang digunakan dalam penelitian ini adalah pendekatan kualitatif. Dalam penelitian ini teori yang digunakan adalah teori representasi. Teknik pengumpulan data yang digunakan adalah teknik observasi, wawancara, mengumpulkan data dari internet serta teknik peradegan. Kemudian objek dari penelitian ini adalah Trailer dari film Suanggi dengan mengambil empat adegan dari trailer tersebut, empat adegan tersebut adalah adegan penelitian di tanah Tidore, adegan tidak direstui oleh orang tua, adegan munculnya Suanggi dan adegan Suanggi yang meresahkan masyarakat. Berdasarkan hasil dari penelitian empat adegan yang didapat dari trailer Suanggi sendiri, dimana budaya Suku Tidore yang direpresentasikan pada trailer film Suanggi seperti: pakaian adat Tidore, Sesajian dan manusia yang bersekutu dengan Suanggi atau yang dipercaya sebagai makhluk yang sering didatangi oleh manusia jika suasana hati seperti sedang dendam atau mempunyai rasa iri hati. Sedangkan untuk nilai kebudayaan yang direpresentasikan suku Tidore dalam trailer Suanggi yang pertama: adanya nilai kepercayaan, dimana kepercayaan terhadap animisme masih diyakini hingga sekarang oleh masyarakat Tidore. Yang kedua: nilai adat istiadat, seperti meminta izin terlebih dahulu kepada petuah jika hendak melakukan sesuatu atau sekedar hanya datang berkunjung.
\end{abstract}

This is an open access article under the $\underline{C C B Y-S A}$ license.

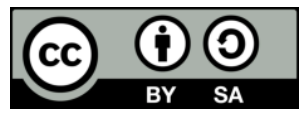

\section{Corresponding Author:}

Yul Isti Masria,

Side Chanel Ahmad Dahlan, Universitas Ahmad Dahlan, Indonesia,

Email: yul@comm.uad.ac.id

\section{PENDAHULUAN}

Indonesia adalah sebuah negara yang berada di Asia Tenggara yang dimana terdiri dari beribu-ribu pulau dan juga termasuk ke dalam negara yang berpenduduk terbesar di dunia. Indonesia sendiri di dalamnya terdiri dari berbagai macam budaya, ras, suku dan agama, namun dengan adanya perbedaan tersebut membuat Indonesia menjadi negara yang memiliki suatu kesatuan yang kokoh (Keesing, 2014). Dengan adanya semua perbedaan tersebut membuat kebudayaan di Indonesia sendiri sangat beragam, karena pada tiap-tiap daerah memiliki kebudayaan yang unik. Berbicara mengenai budaya sendiri, budaya memiliki berbagai macam bentuk dimana kini budaya sendiri telah hadir sebagai pembawa pesan. Sama halnya dengan keberadaan suatu daerah tidak akan hilang dari kebudayaan yang telah dimiliki oleh daerah tersebut, seperti adanya peninggalan sejarah yang tidak boleh kehilangan jati dirinya, adanya bangunan, jalan, bahkan adanya situs maupun candi peninggalan dari nenek moyang terdahulu merupakan kebudayaan yang dimiliki oleh suatu daerah tersebut. 
Budaya yang dimiliki oleh suatu daerah membutuhkan masyarakat yang cerdas karena pentingnya masyarakat yang cerdas akan dapat menjaga kearifan lokal serta mendedikasikan kebudayaan bahkan peninggalan sejarah dari nenek moyang sebelumnya (Fallis, 2013).

Perkembangan zaman yang sangat modern seperti saat ini tidak lari dari kepahitan sebelumnya, media merupakan salah satu komponen yang penting dalam berkembangnya teknologi globalisasi, media juga berkembang dengan sangat pesat dimana media ini sangat terkenal dan berkembang dalam lingkup masyarakat, yang dimana terdiri dari adanya media cetak, media elektronik dan media online.Salah satu media yang dimana menjadi alat penyampaian pesan yang banyak diminati, dimanfaatkan dan sudah menyebar luas di kalangan masyarakat saat ini salah satunya adalah melalui film. Film merupakan salah satu media yang sangat ramai diperbincangkan oleh masyarakat pada saat ini, karena dimana film juga merupakan salah satu media yang termasuk dianggap sangat baik dalam menyampaikan pesan. Menurut Ensiklopedia Indonesia, Kota Tidore sendiri menempati wilayah terluas ketiga yang ada di Indonesia setelah kota palangkaraya dan kota dumai.Budaya dan adat yang ada di Tidore bisa dibilang masih sangat kental, karena dimana di wilayah Tidore merupakan wilayah yang mayoritasnya adalah pemeluk agama Islam, Tidore juga merupakan salah satu kerajaan Islam terbesar yang ada di Indonesia.Membahas tentang kebudayaan yang ada di Tidore, dalam penelitian ini peneliti akan meneliti tentang trailer dari film Suanggi yang dimana di dalam trailer film tersebut mengandung adanya unsur kebudayaan Tidore sendiri, dimana trailer Suanggi sendiri yang menceritakan tentang kehidupan kisah percintaan antara laki-laki dan perempuan yang dimana hubungan mereka tidak disetujui oleh orang tua dan keluarga perempuan, selain itu dimana keluarga mereka adalah dari keluarga bangsawan atau menurut istilah di Tidore adalah keluarga kesultanan. Selain adanya sisi percintaan ada juga kebudayaan atau kepercayaan yang di selipkan ke dalam trailer Suanggi tersebut, dimana pihak laki-laki yang hubungannya tidak disetujui oleh pihak keluarga perempuan sendiri memilih untuk bersekutu dengan Suanggi yang dimana suanggi sendiri dipercaya memiliki ilmu hitam yang sangat kuat dan sudah menjadi sosok yang melegenda di masyarakat Maluku Utara lebih tepatnya di tanah Tidore sendiri, dimana Suanggi juga dalam kepercayaan masyarakat Tidore adalah sesuatu yang jahat atau berkaitan dengan makhluk halus (Oemar, 2013).

Kota Tidore sendiri hingga sampai saat ini masih mempercayai cerita-cerita yang pernah terjadi atau dianggap nyata yang pernah dialami oleh nenek moyang dulu. Sehingga adanya pandangan dari masyarakat luar bahwa mereka percaya tentang adanya hal-hal ghaib seperti ilmu hitam yang digunakan oleh sebagian besar masyarakat Tidore adalah untuk sarana mata pencaharian ataupun balas dendam kepada orang yang sedang dibenci atau pernah manyakiti hati mereka (Dixon, 2016). Alasan mengapa peneliti lebih memilih untuk menganalisis trailer Suanggi dibandingkan dengan menganalisis film Suanggi, yaitu sebelumnya dimana film Suanggi sendiri sudah dihapus oleh pihak rumah produksi atau PT. Putra Tidore yang sebagai tim produksi dari pembuatan film Suanggi sendiri. Ada alasan yang lain juga sehingga film Suanggi harus dihapus salah satunya yaitu adanya masalah anggaran dimana peminat film lokal untuk dapat ditayangkan di layar lebar masih sangat minim sehingga anggaran yang dikeluarkan tidak sebanding dengan hasil yang diterima dan jadilah film yang dianggap gagal produksi. Kenapa budaya Tidore harus direpresentasikan dan apa pentingnya trailer ini untuk masyarakat yaitu dimana dalam trailer Suanggi ini peneliti ingin menyampaikan dan memberikan informasi kepada masyarakat bahwa memang trailer ini jika hanya dilihat begitu saja akan kurang menarik dan bahkan tidak memiliki adanya penghargaan seperti memenangkan beberapa prestasi layaknya film layar lebar lainnya,tetapi yang perlu peneliti tegaskan bahwa yang membuat peneliti ingin menganalisis film ini yaitu dimana peneliti ingin menyampaikan adanya keunikan tersendiri dari trailer Suanggi ini. Keunikan yang peneliti maksud adalah dimana trailer Suanggi ini menceritakan tentang kebudayaan Tidore dan kepercayaan dinamisme yang masih sangat kuat dan masih dipercayai oleh masyarakat Tidore sendiri, selain itu Suanggi ini sendiri merupakan salah satu makhluk yang dipercayai oleh masyarakat Tidore dan masih ada hingga saat ini. Intinya dimana alasan peneliti ingin menganalisis trailer Suanggi ini yaitu dalam konteks untuk menyampaikan kepada komunikan dan khalayak luar bahwa Suanggi sendiri adalah sebuah kepercayaan supranatural atau kepercayaan masyarakat terhadap animisme yang masih kental hingga sampai saat ini (Murphet, 2005).

\section{METODE}

Pada penelitian ini menggunakan Teori Representasi Budaya yang akan mencari tahu Simbol budaya apa saja yang ada pada suku Tidore dalam trailer Suanggi. Dalam hal ini, peneliti akan lebih fokus untuk mendeskripsikan repsesentasi budaya dalam kajian Nilai-Nilai Kepercayaan serta Nilai-Nilai adat Istiadat yang terdapat pada trailer suanggi tersebut (Maimunah, 2014).

Jenis penelitian yang digunakan adalah jenis penelitian yang menggunakan deskriptif kulaitatif dengan metodologi penelitian ataumenggunakanteorirepresentasi. Penelitian kualitatif atau yang lebih dikenal dengan metode penelitian kuliatatif adalah sebuah metode penelitian yang tidak akan menggunakan perhitungan atau dengan menggunakan adanya penemuan-penemuan yang sama seperti dengan metode penelitian kuantitatif 
(Sugiyono, 2015).

Penelitian ini bertujuan untuk dapat mendeskripsikan sebuah penelitian secara sistematis, faktual, dan akurat tentang berbagai fakta-fakta, sifat, simbol dan makna bahkan dalam penyampaian dari suatu populasi atau objek tertentu. Representasi bertujuan untuk dapat menganalisis tanda-tanda yang akan ditelusuri dalam penelitian ini, baik melalui dialog, scene/adegan, setting dan lain sebagainya yang masih berkaitan dengan representasi budaya suku Tidore dalam Trailer Suanggi (Sugiyono, 2016).

\section{HASIL DAN PEMBAHASAN}

Sedikit penjelasan bahwa film Suanggi adalah salah satu film yang termasuk dalam genre film thriller suspance yang dikemas dengan durasi 1 jam 30 menit atau 90 menit dan durasi traile Suanggi sendiri yaitu 2 menit 5 detik. Para tokoh yang ikut andil dalam trailer Suanggi ini yaitu adanya Five Vi sebagai Rosen, Dolly Martin sebagai Rahazan dan merangkap menjadi Suanggi, Rio Pratama sebagai Reza dan Baby Sexyola sebagai Lavina, dan salah satunya yang paling berpengaruh dalam trailer Suanggi ini yaitu seorang produser yang dimana beliau sendiri memiliki sebuah rumah produksi dengan nama PT. Putra Tidore dan sudah memproduksi beberapa film yang ditayangkan secara lokal maupun tidak, misalkan juga seperti salah satu karya beliau yang juga sudah banyak dikenal orang dan sudah tampil di televisi swasta yaitu film Nyong Mutiara Hitam.

Trailer Suanggi sendiri juga mendapat banyak dukungan, bukan hanya dukungan dari kebanyakan orang tetapi juga mendapat dukungan dan apresiasi yang sangat besar dari masyarakat.Maluku Utara khususnya Kota Tidore sendiri, karena dimana cerita yang diangkat dalam trailer Suanggi ini menceritakan tentang kebudayaan alam, kehidupan masyarakat Tidore dan kesehariannya, kekayaan alam, keindahan alam yang tidak pernah diketahui masyarakat luas sebelumnya, kebudayaan serta kepercayaan terhadap suatu hal yang sudah melegenda dan dipercaya adanya hingga sekarang.

Konsep yang digunakan dalam trailer Suanggi ini juga dibuat dengan konsep yang secara nyata seperti kehidupan sehari-hari masyarakat. Trailer Suanggi ini sendiri juga secara tidak langsung dapat menyampaikan pesan dalam cerita tersebut bahkan dalam trailer Suanggi tersebut juga sudah terlihat pesan apa yang akan disampaikan kepada masyarakat luar bahwa pandangan mereka mengenai budaya khas Indonesia bagian Timur khususnya Tidore yang dimana seperti adanya pandangan bahwa masyarakat Maluku Utara adalah orang-orang yang memiliki ilmu hitam, tidak mempunyai kehidupan yang sama seperti yang lainnya serta kebudayaan yang tidak dikenal oleh banyaknya masyarakat luar. Namun, pandangan mereka berbanding terbalik dengan apa yang disajikan dalam cerita trailer Suanggi ini dimana adanya ilmu hitam, sayangnya ilmu hitam tersebut tidak akan digunakan oleh sembarang orang sebagaimana pendapat masyarakat luar, serta peneliti ingin menunjukkan ke masyarakat bahwa alasan mengapa peneliti ingin menganalisis trailer Suanggi ini karena ada suatu keunikan yang tidak diketahui oleh masyarakat luas atau lebih tepatnya yang akan peneliti analisis menggunakan trailer dari film Suanggi sendiri.

Trailer Suanggi ini sendiri adalah salah satu karya dari Ade Muhammad Nur. Dalam trailer ini sendiri menceritakan tentang kehidupan keseharian masyarakat yang ada di Tidore dan bagaimana mereka menyikapi dan mengikuti aturan kebudayaan yang sudah ada. Seperti halnya, dalam suatu kehidupan tentunya akan ada aturan-aturan yang berlaku dalam keluarga maupun lingkungan tempat kita tinggal, sama halnya seperti yang kita lihat dalam trailer Suanggi ini yaitu adanya unsur kebudayaan serta kepercayaan yang sudah sangat kental di masyarakat Tidore sendiri, dimana ada beberapa adegan dalam trailer tersebut yang selalu berkaitan dengan kebudayaan maupun larangan apa saja yang tidak boleh dilakukan dalam kehidupan sehari-hari serta kepercayaan dan adanya sifat alamiah tiap manusia.

\section{KESIMPULAN}

Pada trailer Suanggi ini peneliti mengambil atau menganalisis 4 adegan yaitu, Penelitian di Tanah Tidore, Tidak Direstui oleh Orang Tua, Munculnya Suanggi dan Suanggi yang Meresahkan Masyarakat. Peneliti mengambil 4 adegan tersebut karena jika disimpulkan dari keempat adegan tersebut dimana Budaya Suku Tidore yang direpresentasikan pada trailer film Suanggi yaitu sebagai berikut : Pakaian adat Tidore, Sesajian dan manusia yang bersekutu dengan Suanggi atau yang dipercaya sebagai makhluk yang sering didatangi oleh manusia jika suasana hati seperti sedang dendam atau mempunyai rasa iri hati. Sedangkan nilai Kebudayaan pada budaya Suku Tidore sendiri yang terdiri dari Nilai Kepercayaan dan Nilai Adat Istiadat yang direpresentasikan pada trailer Suanggi. Nilai kepercayaan merupakan kepercayaan dan keyakinan suatu daerah yang sudah lama menjadi kebudayaan serta suatu sikap dan sifat kepercayaan yang memang sudah ada sejak zaman dahulu. Sebagaimana kepercayaan masyarakat di setiap daerah tentang animisme atau yakin dan percaya bahwa adanya makhluk halus seperti jin, roh dan Suanggi yang masih dipercaya hingga sekarang oleh masyarakat Tidore sendiri. Nilai adat istiadat merupakan suatu kebiasaan yang sudah ada sejak lama atau kebudayaan yang sudah tumbuh berkembang serta dijunjung tinggi dan dijadikan suatu kebiasaan oleh masyarakat secara turun-temurun sehingga sudah menjadi kebudayaan dan kebiasaan yang dipercaya oleh masyarakat dari zaman nenek moyang hingga sekarang. Sebagaimana adat istiadat atau kebiasaan yang ada di 
tanah Tidore sendiri seperti kebiasaan meminta izin terlebih dahulu kepada petuah yang menjaga tanah Tidore untuk melakukan penelitian di hutan Tidore maupun hanya sedang berkunjung ke tanah Tidore.

\section{REFERENSI}

Dixon, D. (2016). Film. In The Routledge Research Companion to Media Geography. https://doi.org/10.4324/9781315613178-7

Fallis, A. . (2013). Kearifan Lokal. Journal of Chemical Information and Modeling. https://doi.org/10.1017/CBO9781107415324.004

Keesing, R. (2014). Teori-Teori Tentang Budaya. Antropologi Indonesia. https://doi.org/10.7454/ai.v0i52.3313

Murphet, J. (2005). Point of view. In Narrative and Media. https://doi.org/10.1017/CBO9780511811760.007

Oemar, Y. (2013). Pengaruh Budaya Organisasi, Kemampuan Kerja dan Komitmen Organisasi terhadap Organizational Citizenship Behavior (OCB) Pegawai pada BAPPEDA Kota Pekanbaru. Jurnal Aplikasi Manajemen. https://doi.org/1693-5241

Sugiyono. (2015). Metode Penelitian. Metode Penelitian.

Sugiyono. (2016). Memahami Penelitian Kualitatif. Bandung: Alfabeta. 